ARTICLE

Received 15 Mar 2016 | Accepted 27 Jun 2016 | Published 2 Aug 2016

DOI: $10.1057 /$ palcomms.2016.52

OPEN

\title{
Shakespearean allusion and the detective fiction of Georgette Heyer
}

\author{
Lisa Hopkins ${ }^{1}$
}

ABSTRACT This essay argues that Shakespearean allusion is a recurrent and important factor in the detective novels of Georgette Heyer. Though the master text for Heyer is Hamlet, a variety of Shakespeare plays are referred to, and mention of them functions in multiple ways. Quotations from Shakespeare reveal truths about the characters and comment on their situations and personalities. They also afford points of entry for people previously unacquainted to talk to each other, and finally they have effects in terms of genre, since their presence can, with equal facility, tend towards comic relief (in line with a tradition in goldenage crime fiction of using Macbeth in particular to comic effect) or work to add gravitas and resonance. The use of Shakespearean allusion is thus central to Heyer's technique. This article is published as part of a collection to commemorate the 400th anniversary of William Shakespeare's death.

\footnotetext{
${ }^{1}$ Department of English, Sheffield Hallam University, Sheffield, UK
} 
n Georgette Heyer's A Blunt Instrument, the biblically minded police constable Glass says "Bread of deceit is sweet to a man ... But afterwards ... his mouth shall be filled with gravel", and the detective novelist Sally, who is the nearest the novel has to a heroine, asks "Is that out of the Bible? ... Nearly all the best things are, except those that come out of Shakespeare" (Heyer, 1938: 83). Glass and Sally represent opposite poles in terms of moral values, levels of sophistication and degree of appeal for the reader. Glass, always sure of his own rightness, inflexible and unclubbable, has a certain amount of comedy value, but ultimately turns out to be the murderer. Sally, lively and charming, provides the book with its romantic subplot as it becomes increasingly apparent that she is in love with chief suspect Neville. She is prepared to overlook any crimes that may have been committed by anyone dear to her, whether Neville himself, her sister, or her brother-in-law; as Melissa Schaub justly observes, "Heyer's mystery novels ... use the 'playing fair' motif (the phrase is uttered by several of the early heroines, including Dinah Fawcett and Antonia Vereker). But she was not as programmatically committed to the same definition of honor-placing the public good above personal benefit-as Sayers" (Schaub, 2013: 97). Ultimately, though, Sally does not have to accept the criminality of anyone dear to her because her faith in the basic decency of each of them proves justified, positioning her as the complete opposite of Glass, who believes that almost everyone but himself is sinful (he makes an exception for the butler, a fellow congregationist). That Glass and Sally should also be systematically divided by their preferred source of quotations is typical of the way that Shakespearean allusion works in Heyer. Quotations from Shakespeare reveal truths about the characters and comment on their situations and personalities. They also afford points of entry for people previously unacquainted to talk to each other, providing a lingua franca and allowing for the display of cultural capital, and finally they have effects in terms of genre, since their presence can, with equal facility, tend towards comic relief or work to add gravitas and resonance. Shakespearean allusion is, in short, a part of Heyer's technique in these books, and technique was something on which she prided herself, saying of her nemesis Dorothy Sutherland, editor of Woman's Journal, "With all due respect to Miss Sutherland, \& without wishing to appear unduly conceited, I do not think she can teach me much about the technique of a murder story" (Kloester, 2011: 151); she also declared that "I know it's useless to talk about technique in these degenerate days -but no less a technician than Noël Coward reads me because he says my technique is so good. I'm proud of that" (Kloester, 2011: 359). In the detective novels, allusion to Shakespeare is fundamental to that technique because it allows her to suggest things about mood, character and situation without having to actually confirm whether or not these things are true, which would give too much away to the reader.

Heyer was steeped in Shakespeare. Kloester notes that "Her father read aloud to Georgette from babyhood, telling her tales from Shakespeare and the Bible" (Kloester, 2011: 6), and when she was nine "he and Georgette won great acclaim for their dramatic portrayal of the the moment in Shakespeare's tragedy, King John, when Hubert is about to put out the eyes of little Prince Arthur" (Kloester, 2011: 25). (King John, as we shall see, would later colour an important moment in A Blunt Instrument.) George Heyer, her father, was briefly secretary of the Memorial Theatre at Stratford (Hodge, 1984: 3), and after her marriage to Ronald Rougier and the birth of their son Richard "the Rougier family played Shakespearian games in the evening" (Hodge, 1984: 26). Her first biographer Hodge observes that "Georgette Heyer did not let herself quote Shakespeare much, but her comedy owes his a great deal" (Hodge, 1984: 51). However this reluctance to quote is found only in the historical romances, and even then it is more prominent in the earlier ones than in the late. Heyer herself noted that in the 1958 romance Venetia "my hero ... is rather given to quotation" (Hodge, 1984: 127), and actually so is Venetia: between them they echo Julius Caesar with "lend me your ears" (Heyer, 1958: 7) and "most unkindest cut of all" (Heyer, 1958: 212); As You Like It with "Oh, how full of briars is this workingday world" (Heyer, 1958: 28); Othello with "pestilent, complete knave" (Heyer, 1958: 30) and "My reputation, Iago" (Heyer, 1958: 31); Twelfth Night with "Item, two lips, indifferent red" (Heyer, 1958: 31), "A blank, my lord" (Heyer, 1958: 56), and "build me a willow cabin at your gates" (Heyer, 1958: 310); Antony and Cleopatra with "my salad days" (Heyer, 1958: 55) and "custom had staled her variety" (Heyer, 1958: 90); Much Ado About Nothing with "Everything handsome about you" (Heyer, 1958: 56); and Hamlet with "We could an if we would" (88), "Alas, poor Yorick" (Heyer, 1958: 129), "assumed that virtue" (Heyer, 1958: 149), and "a consummation devoutly to be wished" (Heyer, 1958: 314). We also hear of Old Capulet and Lear (Heyer, 1958: 92), and Romeo and Juliet is directly echoed in "parting is such sweet sorrow" (Heyer, 1958: 284). In The Convenient Marriage the Earl of Rule assures his cousin Crosby, who has tried to persuade him that his wife is unfaithful, that "I am no Othello, Crosby" (Heyer, [1934], 2013: 200); in Regency Buck Peregrine goes to Othello, though it requires some thought for him to be sure that was what he saw (Heyer, [1935b], 2004: 41); and in These Old Shades the supposed Léon is "Puck-like" (Heyer, 1926: 42). Above all, as Diana Wallace observes, there is a Shakespearean structure at work: in These Old Shades in particular, "Heyer is clos[e] to Shakespeare's As You Like It or Twelfth Night where cross-dressing allows the girl-page heroine the carnivalesque freedom to enter 'male' spaces and encounter the hero without a chaperone" (Wallace, 2005: 39).

Heyer's first novel, Black Moth, was published when she was only 19, and was a historical romance of the kind which was to make her famous. She turned to detective stories in the early thirties, for reasons very much bound up with the family life which was all-important to her (the first of her detective novels, Footsteps in the Dark, was published the same day her son was born): her husband was fond of the form and collaborated on these stories with her, devising the plots and seeing to the technical details while she concentrated on the characterisation, and the sudden influx of barristers and solicitors, as heroes coincided with his decision to start studying for the bar. Heyer drew a clear distinction between the detective novels and the romances which had made her famous. Hodge notes that from 1932 "Georgette Heyer was aiming to write one historical and one detective novel a year" (Hodge, 1984: 30). However for Heyer, supporting a widowed mother, a brother who suffered from haemophilia and manic depression, and another brother who was only 13 when their father died, putting her husband through 3 years of training for the bar, and locked in permanent combat with the Inland Revenue, money always mattered, and she could hardly fail to notice that the historical romance "Devil's Cub, published in the same year as Footsteps in the Dark, had a printing of 115,000 copies as against 16,000 for Footsteps in the Dark" (Hodge, 1984: 32). She had to prioritise writing the historical novels which were her bread and butter, so her 11 detective novels appeared at intervals rather further apart than she had at first envisaged. Along the way, they changed in character- "she described Death in the Stocks ... as 'The first of what I call my real crime stories' " (Hodge, 1984: 36) -and also in publisher Hodge observes that Heyer "moved to Hodder \& Stoughton with her fifth detective story, Behold, Here's Poison, perhaps because she was dissatisfied with Longman's printing of only 5,000 for Death in the Stocks, the same number as for The Unfinished Clue, and fewer than for Why Shoot a Butler?" (Hodge, 1984: 36-37). Even with a new publisher, though, the 
detective novels never rivalled the success of the historical romances, and the sales figures for the last one make clear why it was the last one: "Cotillion and Detection Unlimited both came out in 1953, with printings of 63,000 and 37,000 respectively" (Hodge, 1984: 97).

Heyer's 11 detective novels contain references to several of Shakespeare's plays. The title of Behold, Here's Poison comes from Pericles; unable to think what to call it, Heyer had turned to a Shakespeare concordance, and had initially hesitated between the eventual title and "Timeless End" from Romeo and Juliet (Kloester, 2011: 151). They Found Him Dead she took from King John (Kloester, 2011: 158). In Detection Unlimited, Miss Patterdale has two goats called Rosalind and Celia (Heyer, 1953: 42) after the two female leads of As You Like It, and feels that she herself looks like the one named Rosalind (Heyer, 1953: 44). In Penhallow (Heyer, 1942), the opening epigraph is taken from Measure for Measure and the whole plot hinges on bastardy: the fact that there is actually a character known universally as Jimmy the Bastard eventually proves to be a red herring, but Raymond's discovery of his own illegitimate birth prompts his suicide and ensures that the actual murderer (his stepmother Faith) will never be identified. Measure for Measure can also be seen as a lurking presence in These Old Shades and Devil's Cub, where an apparently omniscient duke disguises himself to bring about justice and arrange marriages, but here the allusion is submerged, whereas in Penhallow it is overt. Penhallow is the oddest of all Heyer's detective stories, and indeed odd on any terms. Her first biographer Hodge saw it as designed deliberately to induce Hodder and Stoughton to break her contract, since its famously strait-laced chairman would be appalled by the bastardy theme, and enable her to defect to Heinemann and to a new literary editor in the shape of A. S. Frere, with whom she was to work productively for the next 30 years (Hodge, 1984: 54); however, her later biographer Kloester thinks the book meant much more to Heyer than that, and notes her pride that her friend Carola Oman "calls it my 'Lear" (Kloester, 2011: 241). Here, Shakespeare signals gravitas, and the epigraph from a problem play prepares us for the unsettling nature of the story and its profound moral ambiguity.

Heyer is particularly fond of Macbeth. In Detection Unlimited, Gavin Plenmeller, asked why Warrenby wanted to enter his house, replies "Vaulting ambition, perhaps. It may be said to have o'erleapt itself" (Heyer, 1953: 206). The quotation from Macbeth signals a truth: Gavin has killed not only Warrenby but his own half-brother Walter, and his motivation was to possess Walter's house and estate, the same reasons that prompted Macbeth to murder Duncan. Normally, though, Macbeth works rather differently. In Death in the Stocks, the story centres on the Vereker family, which consists of four siblings of whom two are murdered. The remaining two react to both the fact of murder and to being personally suspected of it in comically inappropriate ways, ranging from intellectual speculation about who really did it to callously cheeful guesses about who the next victim might be, coupled with a wilful refusal to cooperate with the police except when absolutely forced to by their saner cousin Giles. Like Sally and Neville, who "never speak of the murder in anything but a dispassionate way, frequently ironically" (Schaub, 2013: 97), the Verekers' social interchanges are so unconventional that Antonia at one point remarks to her brother that Rudolph, to whom she is rather half-heartedly engaged, "doesn't altogether understand us when we speak, Kenneth", to which Kenneth's fiancée Violet retorts, "It would be rather difficult for the average man to understand you when you speak, as you call it" (Heyer, 1935a: 127). The key to the Verekers' erratic, allusive conversational style is given to the reader in a description of their flat:

There was no sitting-room in the Verekers' flat other than the big studio. Supper was laid on a black oak table at one end, after one dog-whip, two tubes of paint, The Observer (folded open at Torquemada's crossword), Chambers's Dictionary, The Times Atlas, a volume of Shakespeare, and the Oxford Book of Verse had all been removed from it. (Heyer, 1935a: 51)

Shakespeare has only nominally been removed, however, because he continues to be sprinkled liberally through the Verekers' conversation. When Kenneth Vereker is led off to prison, he seems unperturbed, requesting only that his sister Antonia should pack his sketching-block because "I'm going to do a series of black-andwhite policemen. After you-Macduff!" (Heyer, 1935a: 278). Kenneth is not the murderer, though the police think he may be, so his temporary identification with Macbeth is not born of guilt; rather it is simply part of his ironic, self-aware, unemotional social self. Knowing both that he is not actually guilty and that the police nevertheless believe him so, he does not trouble to protest but simply plays as cast.

Kenneth's decision to turn policemen into figures of fun by sketching them is very much in line with a tradition in golden-age crime fiction of using Macbeth to comic effect. In Ambler's The Mask of Dimitrios, the hero Latimer reflects that "Fortunately, or unfortunately, he, Latimer, had a Lady Macbeth in the person of $\mathrm{Mr}$ Peters. He decided to go out to breakfast" (Ambler, 1939: 258). The note of bathos here is found also in Alan Melville's Quick Curtain, where the theatre critic James Amethyst (based transparently on the real-life James Agate) quips to a fellow critic named Duncan during the interval "Was that the bell?-summoning us to Heaven, or much more probably to Hell? Hear it not, Duncan. There's time for another one" (Melville, 1934: 25), and in Sayers' The Nine Tailors, where Bunter after the wiping of the fingerprints from the beer bottle declares "There, madam, is his morning tea, only waiting for my hand to put the boiling water to it, and I feel, madam, as though it were the hand of a murderer which no perfumes of Arabiasupposing such to be suitable to my situation-could sweeten" (Sayers, 1934: 206). In each of these cases, what matters is the contrast between the smallness of what is actually at stakebreakfast, another drink at the bar, and the serving of morning teaand the size and weight of the sense of tragedy evoked by allusion to Macbeth. All three, though, also share another element, which is that they all link Macbeth to meals, and in this too they are typical of golden-age crime fiction as a whole; Agatha Christie in particular repeatedly connects Lady Macbeth with food, and specifically with milk (see Hopkins, 2016: 31-33).

Heyer too uses Macbeth for both comic and culinary effect in $A$ Christmas Party (first published as Envious Casca, though $A$ Christmas Party was in fact the title Heyer originally envisaged) where Paula is early identified as a potential Lady Macbeth: she "had a beautiful voice, like a stringed instrument. It was mellow, and flexible, which made her the ideal choice for a Shakespearean role" (Heyer, 1941: 17), and which particular role is soon specified. When she makes a scene about wanting money to act in a play, her brother cruelly responds, "All I beg is that you won't stand there ranting like Lady Macbeth. Too much drama in the home turns my stomach, I find" (Heyer, 1941: 69). Almost immediately afterwards Nathaniel, the uncle who stands between Paula and the money, is stabbed. On the discovery of the body, Joseph, the victim's actor brother, cries, "Fetch a mirror! If we hold it in front of his lips-" (Heyer, 1941: 85), suggesting Lear, but Paula reverts to Macbeth, exclaiming "How horrible! How horrible!" (Heyer, 1941: 88) and then "This house!" (Heyer, 1941: 89). The motif is sustained for some time. One of the most delicious aspects of Heyer's novels is the way she anatomises the etiquette dilemmas posed by the murder of a disliked family member just before a meal is due to be served: does one consume the soup and sole, or does one let them go to waste? In A Christmas Party, this difficulty is tackled head on as soon as it has been discovered that the reason for Nathaniel's 
failure to appear for pre-dinner drinks is that he is dead: "We can have dinner', said Paula, brusquely putting into words the unworthy thought in more than one mind" (Heyer, 1941: 95). Once dinner is actually served, the "vacancy" (Heyer, 1941: 98) at the head of the table prompts Joseph to observe "I can't help feeling glad that for just this one evening I see only Nat's empty chair” (Heyer, 1941: 99); since Joseph is in fact the murderer, he is indeed fortunate, since the alternative might have been his victim's ghost, but Heyer's is a world of quiet social comedy rather than great events. Later, told by the police that she had been seen coming away from her uncle's room, Paula demands "Did I have a bloodstained dagger in my hand?" (Heyer, 1941: 138), nonplussing the inspector who can only admit that she did not, and Macbeth is also comically evoked by Val's mother: "'If only my Val had not been in the house!' said Mrs Dean, apparently stating her only objection to the murder" (Heyer, 1941: 189).

A Christmas Party is a classic example of what one might term the Christmas crime genre: Joseph assures his wealthy older brother Nathaniel that he will provide "a real English Christmas", upon which "Nathaniel, regarding him with a contemptuous eye, said that a real English Christmas meant, in his experience, a series of quarrels between inimical persons bound to one another only by the accident of relationship" (Heyer, 1941: 5-6), and Mathilda is quite right to prophesy that "there'll be murder done before we're through" (Heyer, 1941: 15). However, when it was first published in 1941 its original title was Envious Casca, and Casca is of course a character in Julius Caesar, a text also recalled in Footsteps in the Dark when Mrs Bosanquet suggests there might be a skeleton in the wall: "'Oh Aunt Lilian, Aunt Lilian!' groaned Charles. 'Et tu, Brute!'” (Heyer, 1932: 15). Charles's reaction arises from the fact that his wife Celia is already prone enough to imagine ghosts and ghouls without any further encouragement, but connecting Brutus to someone named Aunt Lilian introduces a note of comedy into the proceedings that clearly signals that Charles is exasperated rather than seriously annoyed. Footsteps in the Dark, written when she was pregnant, was Heyer's own least favourite among her detective novels, and indeed by the time Detection Unlimited came out she was asking for it to be actively suppressed, a strategy she adopted with a number of her early books; she also noted that both her brothers as well as her husband had collaborated in it (Hodge, 1984: 98). Nevertheless the introduction of Julius Caesar, however brief, does sound the authentic Heyer note, and prefigures the more sustained awareness invited by the title of Envious Casca.

A particularly suggestive use of Shakespearean quotation comes in A Blunt Instrument, where Neville, wrongly suspected of the murder of his uncle, says "Oh, no! This hand of mine Is yet a maiden and an innocent hand, Not painted with the crimson spots of blood" (Heyer, 1938: 145). The lines are from King John, and are spoken by Hubert, who has been deputed to murder the young Prince Arthur but has not actually done so. They are apposite because the person who has ordered Hubert to murder Arthur is the boy's uncle, King John, who is worried that Arthur's claim to the English throne is better than his own. Hubert is moved by Arthur's pleas and does not carry out the murder, but Arthur, impatient of captivity, jumps from the wall of his prison and dies anyway. In the case of Neville the relationship is reversed -nephew might have murdered uncle rather than vice versabut there are also two parallels. First, Neville too escapes from the house via an upper window as soon as the murder of his uncle has been discovered, and second the victim, like Arthur, has died as a result of something he himself did: Neville's uncle Ernest Fletcher seduced and subsequently abandoned P.C. Glass's sister, which has led Glass to kill him and also led A Blunt Instrument to be rejected for serialisation by Dorothy Sutherland, editor of The Woman's Journal, on moral grounds (Kloester, 2011: 186), a blow to Heyer who always hoped to supplement her income from the detective stories by having them serialised. Sutherland had a point, because A Blunt Instrument is risqué for its time in treating both the story of Angela Angel, a "fallen woman", and the marital troubles of Helen North in a studiedly neutral way that never allows any suggestion of blame or flightiness to accrue to either woman. What the book does have, though, is an aesthetic code in which value is to be placed on restraint, understatement and style, and this is symbolised by the use of Shakespeare.

In addition, there is another lurking parallel between Heyer's novel and the Shakespeare text it quotes. King John owes its place in the theatrical repertoire primarily to Constance, whose great speech about grief made her a favourite character for actresses and audiences. A Blunt Instrument is very interested in the expression of grief. Glass refuses to grieve for the sister he sees as a sinner, and allows himself instead to become obsessed by revenge for something he cannot admit that he cares about. The only person who really grieves for Ernest Fletcher is his sister, and as Sally comes to realise, Neville has gone to some trouble to alleviate that grief by distracting his aunt's attention with a series of acts which appear thoughtless but are actually carefully and considerately calculated. Discovering that Neville has concealed the date of the inquest from his aunt so that she will not feel obliged to attend it, Sally says admiringly, "I hand it to you, Neville ... You've been a brick to Miss Fletcher" (Heyer, 1938: 212). Elsewhere in A Blunt Instrument, Hannasyde's description of John North as "noble" elicits an appalled reaction from Sergeant Hemingway: " 'Regular film star, he sounds to me,' said the Sergeant, revolted. 'Red blood, and hair on his chest, too, I should think'". Neville by contrast does not have hair on his chest, and the first thing we are told about him has implications which call his masculinity into question: he is "a willowy young man ... who paused on the threshold, blinked long-lashed eyelids at the sight of a policeman, and smiled deprecatingly" (Heyer, 1938: 5). Ten years before Heyer wrote A Blunt Instrument, Patricia Wentworth in the first of her Miss Silver novels, Grey Mask, had a character explain that "Men don't have eyelashes ... It's not done" (Wentworth, 1928, 2006: 243); Neville's long lashes might therefore be a signifier of effeminacy, and indeed Sergeant Hemingway judges him as "hardly having the strength to stand up without holding on to something" (Heyer, 1938: 45). However, Superintendent Hannasyde informs him that he is mistaken: "That weary young man holds the record for the high jump. Got a half-blue at Oxford" (Heyer, 1938: 45), or as Neville himself puts it, "though I may look effeminate I'm not really" (Heyer, 1938: 137).

It is part of Neville's assumed effeteness that he absolutely disclaims Sally's compliment that he has been a brick to his aunt: "He gave an anguished sound. 'I haven't! I wouldn't know how! You shan't tack any of your revolting labels on to me!' " (Heyer, 1938: 212). Nevertheless the reader has by now become aware that Neville does show a quiet, understated adherence to a rigid moral code. This concealment of an inner moral fibre is something characteristic of Heyer's heroes: Schaub observes that "Her preference in all her novels is for characters who have a cool manner" (Schaub, 2013: 112), and Heyer herself described the Earl of Rule in The Convenient Marriage as "Hero of the best type. Very pansy, but full of guts under a lazy exterior" (Kloester, 2011: 130). Rule, like Neville, is first introduced to us as a "lazy, faintly mocking exquisite" (Heyer, 1935a: 14), but in his case, as in Neville's, appearances are deceptive: “just as his lordship's laced and scented coats concealed an extremely powerful frame, so his weary eyelids drooped over eyes that could become as keen as the brain behind" (Heyer, 1935a: 14). A central concern in all Heyer's fiction, both the detective stories and the historical romances, is ways of inhabiting gender. In Regency Buck, arguably the most famous of all Heyer's novels, the emphasis is almost as much on Peregrine's learning to be a man as on the romance between Judith and Lord Worth; 
in These Old Shades Léonie, disguised as a boy for 7 years, has to relearn how to be a girl. In A Blunt Instrument, where Neville's first substantive remark, after he has seen the murdered body of his uncle, is "I should shame my manhood if I were sick, shouldn't I?" (Heyer, 1938: 5), the allusion to King John helps to point up the ways in which Neville fits into this pattern, since it speaks of both a mannered exterior and a serious interior. It can do this because Shakespeare allows us to see into people as allusions from the Bible do not. When Neville comes back at Glass with "Am I a sea or a whale that thou settest a watch over me?" (Heyer, 1938: 139) Sally and the Sergeant are tickled, but not informed. By contrast, Sally's response to the lines from King John may be "quotations prove nothing" (Heyer, 1938: 145), but she is wrong: when they are from Shakespeare, they may well prove something.

A Blunt Instrument was first published in 1938, and it is typical of novels of the period in using Shakespeare to reveal truth in this way. The same year saw the publication of Margery Allingham's The Fashion in Shrouds, Agatha Christie's Appointment with Death and Hercule Poirot's Christmas, and Freeman Wills Crofts' Antidote to Venom. In Appointment with Death the youngest child Ginevra, who reminds observers of Ophelia (Christie, 1938a: 227), eventually acts the role. In Hercule Poirot's Christmas, when the body of Simeon Lee is discovered his daughter-in-law Lydia, who occupies Lady Macbeth's position of châtelaine, asks "Who would have thought the old man to have had so much blood in him?" (Christie, 1938b: 97), and this eventually gives Poirot the clue that the murderer is a member of the family and that "It is Simeon Lee's own blood that rises up against him" (Christie, 1938b: 315). In Antidote to Venom George Surridge, planning murder, "screw[s] up his courage to the sticking point" (Crofts, 1938: 39), but then, like Macbeth, cannot sleep (Crofts, 1938: 187) and wonders how he ever came to commit murder for so paltry a reward (Crofts, 1938: 183); like Hamlet, too, he wonders whether there is life after death (Crofts, 1938: 259) but dares not kill himself until he has cleared his conscience (Crofts, 1938: 260). In each of these cases allusion to Shakespeare helps readers (and perhaps also the detective) to understand something fundamental about one or more of the characters, just as it does in $A$ Blunt Instrument. Early in the book, Neville tells Sally that in the detective novels she writes "You always draw your characters rather more than life-size" (Heyer, 1938: 37), so that they all display more brains and gumption than they could really be expected to possess. Heyer herself does not do this: hers is more the iceberg approach, allowing us to guess at hidden depths but never displaying them. Neville in particular is, as John North observes, "extremely detached" (Heyer, 1938: 153). His aunt attributes this to his never having "known a mother's love" (Heyer, 1938: 50), a recurrent motif in Heyer (Wallace, 2005: 41), and the book offers oblique support for this thesis when Neville himself opines that "Mothers say they know their children through and through. Fallacy. Rather disgusting, too" (Heyer, 1938: 53). Instead he believes that "one doesn't know people" (Heyer, 1938: 53). For such reticent, self-aware souls as Neville, whose standard mode is irony, Shakespeare offers an opportunity for vicarious self-expression, and allows the reader to infer things about characters which the code of irony and understatement does not allow to be revealed by any other means.

No Wind of Blame, which was published the year after A Blunt Instrument and has at its heart the hilariously self-dramatising Vicky and her actress mother Ermyntrude, alludes to a variety of different plays. Vicky's stepfather Wally, who is about to be murdered, tells Dr Chester, "And if you want my advice, don't you ever marry an actress, unless you're the kind of man that likes having a wife who carries on like Lady Macbeth and the second Mrs Tanqueray, and Mata Hari, all rolled into one! Before breakfast, too!" (Heyer, 1939: 97), again using Macbeth for comic effect. Ermyntrude and Vicky milk every situation for maximum dramatic potential, and also show a typically Heyeresque lack of concern for the proprieties: when it is suggested that Vicky might have shot Wally, Ermyntrude reflects that perhaps it was only to be expected given that Vicky's real father was a big game hunter, and laments "I ought to have seen to it my Vicky had a chance to shoot bigger things than just a few rabbits here and there" (Heyer, 1939: 248), which is splendidly followed by the narrator's quiet rephrasing of Ermyntrude's remark as a "suggestion that Vicky, finding rabbits poor sport, had added her stepfather to the bag" (Heyer, 1939: 248). Later, when Hugh doubts the existence of Wally's aunt the inspector assures him that "he went so far as to say that she lived in Chipston", to which Hugh replies "H'm! Giving a local habitation and a name to an airy nothing, perhaps" (Heyer, 1939: 304), an allusion to A Midsummer Night's Dream which is doubly apt, firstly in that the events of Dream are set in motion by Lysander's plan to take Hermia to his aunt and secondly in that the reference to Dream captures more generally the rampant metatheatricality of this text in which Inspector Hemingway says of Vicky "Don't tell me the Duchess of Malfi isn't on the stage, because I wouldn't believe you!" (Heyer, 1939: 240). Finally when Vicky declines to ride in Hugh's car on the grounds that "I dressed specially for a Rolls-Royce, and I wouldn't look right in an open tourer", he replies, "All right, Shylock! have your pound of flesh! I apologise for having spoilt your act" (Heyer, 1939: 310). The allusion is of course to the scene in The Merchant of Venice in which the cross-dressed Portia gives a bravura performance to ensure that the threatened excision of a pound of Antonio's flesh will not in fact occur. By calling Vicky Shylock, Hugh is acknowledging the artificiality of her performance, but also implicitly accepting its status as theatre-and hence appealing to spectators-and his own willingness to participate in it. It comes as no surprise that he proposes to her very shortly after.

The master text for Heyer, though, is Hamlet. The title of No Wind of Blame comes from Hamlet, and in it Vicky says to Mary, "You can't pretend it would be a cherishing short of thing to do to let Ermyntrude marry Alexis. The more I consort with him, the more I feel convinced he's exactly like somebody or other in Shakespeare, who smiled and smiled and was a "villain" (Heyer, 1939: 150); the somebody or other is of couse Claudius in Hamlet. Detection Unlimited takes its title from the fact that virtually everyone in the community has a pet suspect for the murder of Sampson Warrenby (the criminal is eventually revealed to be a detective novelist), but also recalls Polonius' "poem unlimited". Hemingway's view that there is "no sense in us treading on one another's heels" (Heyer, 1953: 147) could also glance at Hamlet IV. vii.162, "One woe doth tread upon another's heel", as does Mrs Ainstable's reference to Gavin Plenmeller being "Hoist with his own petard" (Heyer, 1953: 181). In A Blunt Instrument Neville, whose uncle has just been murdered, examines Helen's shoes, which provide evidence of her presence at the scene of the crime, and says, "O my prophetic soul! Now we are in a mess, aren't we? Just like your pretty little slippers" (Heyer, 1938: 23), echoing Hamlet's "O my prophetic soul! My uncle!” (I.v.41). In Duplicate Death (Heyer, 1951), the maid Elsie is charmed to discover that her evidence is valued by the police, until the butler takes a hand: "Thrimby, listening-in, in the pantry, to a brief conversation on the telephone between his mistress and Lord Guisborough, was able to depress these pretensions by assuming the air of an informed person, and by throwing out such doubtful phrases as Hamlet warned his friends never to utter" (Heyer, 1951: 212). In The Unfinished Clue (Heyer, 1933), the apparently vacuous Camilla Halliday greets the departure of the odious Mrs Chudleigh with "For this relief much thanks!" (Heyer, 1939: 86; Shakespeare, 1982), and in Footsteps in the Dark, when a skull bounces down the stairs and a skeleton is subsequently found in the wall, Charles when examining the hole in which it has been concealed exclaims "Faugh! what a smell of must!" (Heyer, 1932: 32; cf Hamlet V.i.194). Later, having fallen into some mud, Charles accepts the offer of whisky but says "don't 
overdo the soda! Too much of water hast thou, poor Charles Malcolm" (Heyer, 1932: 55; Shakespeare, 1982). Shortly after this movement is heard in the cellars, which Charles and Peter go to investigate, and after Mrs Bosanquet actually sees the monk she says "I can see its eyes now", upon which Celia demands 'Where?' and Mrs Bosanquet clarifies, "In my mind's eye" (Heyer, 1932: 93; Shakespeare, 1982). Later, Mrs Bosanquet regrets that she did not ask the apparent ghost what it wanted (Heyer, 1932: 95), which is one of Hamlet's main aims in visiting the battlements. The final verbal echo comes when Peter says they have had no luck fishing because "there's too much sun" (Heyer, 1932: 110; Shakespeare, 1982). In all these cases Hamlet works as Macbeth does, injecting an element of comedy and pointing up the contrast between the high drama of Shakespeare's tragedies of state and the much lighter and more domestic focus of Heyer, and it also allows the reader the pleasure of recognition, for even if a reader of Heyer's novels was not particularly familiar with Shakespeare's play directly, allusion to Hamlet is so much a stape of golden-age crime fiction that it would be hard not to learn by osmosis.

The apogee of the Hamlet motif is Death in the Stocks (also, and perhaps not coincidentally, the one detective novel on which Heyer's husband did not collaborate, so that she had a completely free hand). Hamlet is introduced when Kenneth explains that Violet does not want to marry him so soon after the murder of his half-brother because she has

'Religious scruples. Respect due to the dead. All against the funeral baked-meats coldly furnishing forth the marriage tables. Romeo and Juliet,' he added.

'Hamlet,' said the Superintendent coldly.

'Shakespeare, anyway'. (Heyer, 1939: 86)

In Innes's Hamlet, Revenge! the Duke, wondering how much of Hamlet he needs to explain, "looked speculatively at Appleby: the higher constabulary might be expected to know a little Shakespeare" (Innes, 1937: 94). Here Superintendent Hannasyde passes the test more easily than Kenneth, but Kenneth redeems himself when the Superintendent brings up the fact that he would have had a financial motive for killing his half-brother:

There was a note of irony in the Superintendent's level voice, and at the sound of it Kenneth turned, not put out of countenance, but alert, and with his sullen ill-humour gone in a flash. His eyes held a challenge, his elf-smile reappeared. " $\mathrm{A}$ hit, a very palpable hit!”. (Heyer, 1939: 178)

When Hannasyde asks Kenneth another question and receives no immediate answer, he too quotes Hamlet:

\section{" "Another hit. What say you?" \\ Kenneth laughed, and said with a good deal of delight: “ "A touch, a touch, I do confess." You know, I'm beginning to like you quite a lot.'}

'I might return that compliment, if it occurs to you to stop trying to hoodwink me. You are fond of quoting from Hamlet (though not always sure of your source), so I will give you one more line to digest: “Take care that you don't become as a woodcock to your own springe"'. (Heyer, 1939: 178)

Kenneth subsequently addresses Hannasyde as "Osric", who is of course a character in Hamlet, upon which his other halfbrother Roger observes with typical Vereker tongue-in-cheekness "It's getting a bit too high-brow for me. Is his name Osric? I thought you said it was Harrington" (Heyer, 1939: 178). Kenneth's disingenous assurance that he himself is not being disingenuous causes Hannasyde merely to "smil[e] faintly", upon which "Antonia, watching him, said dispassionately, "They bleed on both sides.' I hoped I'd be able to get that one off sooner or later" (Heyer, 1939: 179). Many pages later, after Roger himself has been murdered, Kenneth is still calling Hannasyde "friend Osric", but Hannasyde no longer wants to play: "You have reminded me yourself that I am not a Vereker ... I don't joke on such matters" (Heyer, 1939: 252). The reader, though, is presumably still entertained.

Despite the title's reference to Julius Caesar, the true master text of Envious Casca/A Christmas Party is also Hamlet. Joseph, the benign-seeming uncle who turns out to be in fact the villain, had been an actor. He claims to have played Hamlet (Heyer, 1941: 22), Benedick (Heyer, 1941: 22), Macbeth (Heyer, 1941: 45), and Romeo (Heyer, 1941: 159), but his wife quashes such pretensions with her remark that "he was very good in character-parts", upon which "Everyone immediately saw Joseph as the First Gravedigger” (Heyer, 1941: 45). “ 'The ideal Polonius!' Mathilda Clare had once called him" (Heyer, 1941: 4). Stephen, the nearest the novel has to a hero, has been rendered bitter and cynical by the remarriage of his mother (Heyer, 1941: 36) and is persecuted by his father's brother, echoing Hamlet's own situation. The name of Willoughby Roydon's play is Wormwood, echoing Hamlet's description of how he hopes the play-within-the-play is operating on Claudius and Gertrude, and Hamlet is also verbally echoed when Nathaniel says he has sciatica: "'The ills the flesh is heir to!' said Mottisfont, shaking his head" (Heyer, 1941: 14). Here, again, Shakespeare tells true: Hemingway, solving the crime, points out that Joseph's affection for Stephen is clearly feigned because "When Stephen was a kid, Joseph was drifting about the world creating a sensation with his masterly portrayal of Mine Host of the Garter Inn, and Snug the Joiner, and very likely a First Citizen as well, not to mention a Soothsayer, and William, a Country Fellow" (Heyer, 1941: 341); he also points out that Joseph's technique depends on hinting (Heyer, 1941: 345), making him into an Iago figure. Arguably most telling is Hemingway's declaration that "Joseph can tell me all he likes about playing Hamlet, and Othello, and Romeo: I don't believe him, and, what's more, I never did. He's got Character-part written all over him ... he was the First Gravedigger in Hamlet" (Heyer, 1941: 337). Hemingway is completely right, for Joseph is indeed a gravedigger in the sense that it is he who has provided the body which now needs interring.

In Envious Casca, we see one last effect of Shakespearean allusion, because it is clear here that one of the main things Shakespeare does is supply culture of an acceptable sort. Mathilda says of Willoughby Roydon's play "Sunday performance, and an audience composed of intellectuals. I know!" (Heyer, 1941: 19); later the inspector echoes her with "Sunday evenings, eh? Uplift and Modernism. I know" (Heyer, 1941: 170), to which Hemingway responds "Can't stand highbrows at any price" (Heyer, 1941: 170). This is a remark typical of detective stories of the period. In Agatha Christie's They Came to Baghdad, for instance, Victoria observes "I went to the British Museum once. It was awful, and dreadfully tiring on the feet" (Christie, 1951: 227) and confesses "I never quite got around to Milton ... But I did go and see Comus at Sadler's Wells and it was lovely" (Christie, 1951: 228-9).

In Georgette Heyer's detective fiction Shakespeare may not be lovely, given that he is usually represented by plays in which people die horribly, but he is never less than edifying, and seeps deep into the fabric and flavour of the narrative. In the first place, he is not the Bible. The reason that Glass in A Blunt Instrument values the Bible is that it preaches morality; the reason Heyer values Shakespeare is that he does not. In Penhallow, an epigraph taken from Measure for Measure prefaces a story in which a murderess escapes justice and a son dies for the sins of his parents, since Raymond commits suicide not because of anything 
he himself does but because he discovers that he is illegitimate. Sometimes Shakespeare's failure to preach extends to a failure to match the official tone of an occasion: in both Envious Casca/A Christmas Party and Death in the Stocks, Macbeth is used to comic effect, and in Death in the Stocks, Hamlet is also deployed for the same purpose. Shakespeare can also be used to drop hints about possible plot developments, in ways which may or may not provide a reliable guide for the reader, as in A Blunt Instrument where Neville, suspected of the murder of his uncle, quotes both from King John, in which an uncle wishes his nephew dead, and Hamlet, in which Claudius and Hamlet, uncle and nephew, each aim to kill the other. Above all, Shakespeare sets the stylistic and aesthetic tone for Heyer's books. Quotations from Shakespeare help her to show rather than tell, and to allow character to be revealed rather than explained. Heyer's husband might have been her most regular collaborator, but it is Shakespeare who provides the most assistance in shaping and telling her stories.

\section{References}

Ambler E ([1939] 1999) The Mask of Dimitrios. Pan: London. Christie A ([1938a] 2001) Appointment with Death. HarperCollins: London. Christie A ([1938b], 2001) Hercule Poirot's Christmas. HarperCollins: London. Christie A ([1951] 2003) They Came to Baghdad. HarperCollins: London. Crofts FW ([1938] 2015) Antidote to Venom. The British Library: London. Heyer G ([1926] 2004) These Old Shades. Arrow: London. Heyer G ([1932] 2004) Devil's Cub. Arrow: London.

Heyer G ([1932] 2006) Footsteps in the Dark. Arrow: London. Heyer G ([1933] 2006) The Unfinished Clue. Arrow: London.

Heyer G ([1934] 2013) The Convenient Marriage. Arrow: London.

Heyer G ([1935a] 2006) Death in the Stocks. Arrow: London.

Heyer G ([1935b] 2004) Regency Buck. Arrow: London.

Heyer G ([1938] 2006) A Blunt Instrument. Arrow: London.

Heyer G ([1939] 2006) No Wind of Blame. Arrow: London.

Heyer G ([1941] 2006) A Christmas Party [Envious Casca]. Arrow: London.

Heyer G ([1942] 2006) Penhallow. Arrow: London.
Heyer G ([1951] 2006) Duplicate Death. Arrow: London.

Heyer G ([1953] 2006) Detection Unlimited. Arrow: London.

Heyer G ([1958] 2004) Venetia. Arrow: London.

Hodge JA ([1984] 2006) The Private World of Georgette Heyer. Arrow: London.

Hopkins L (2016) Shakespearean Allusion in Crime Fiction: DCI Shakespeare.

Palgrave Macmillan: Basingstoke, UK.

Innes M ([1937] 2001) Hamlet, Revenge!. Stratus: Kelly Bray, UK.

Kloester J ([2011] 2013) Georgette Heyer: The Biography of a Bestseller. Arrow: London.

Melville A ([1934] 2015) Quick Curtain. The British Library: London.

Sayers DL ([1934] 1959) The Nine Tailors. Four Square: London.

Schaub M (2013) Middlebrow Feminism in Classic British Detective Fiction: The Female Gentleman. Palgrave Macmillan: Basingstoke, UK.

Shakespeare W (1982) Hamlet. In: Jenkins H (ed). Methuen: London.

Wallace D (2005) The Woman's Historical Novel: British Women Writers, 19002000. Palgrave Macmillan: Basingstoke, UK.

Wentworth P ([1928] 2006) Grey Mask. Hodder and Stoughton: London.

\section{Data availability}

Data sharing not applicable to this article as no data sets were generated or analysed during the current study.

\section{Additional information}

Competing interests: The authors declare no competing financial interests.

Reprints and permission information is available at http://www.palgrave-journals.com/ pal/authors/rights_and_permissions.html

How to cite this article: Hopkins L (2016) Shakespearean allusion and the detective fiction of Georgette Heyer. Palgrave Communications. 2:16052 doi: 10.1057/ palcomms.2016.52

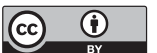

This work is licensed under a Creative Commons Attribution 4.0 International License. The images or other third party material in this article are included in the article's Creative Commons license, unless indicated otherwise in the credit line; if the material is not included under the Creative Commons license, users will need to obtain permission from the license holder to reproduce the material. To view a copy of this license, visit http://creativecommons.org/licenses/by/4.0/ 